\title{
The Effect of Health Education on the Knowledge and Attitude of Brides and Grooms in the Community Health Center of Duri Pulo Village Gambir Sub-District in 2020
}

\author{
Miftah Rizqah, Retno Widowati*, Triana Indrayani \\ Faculty Of Health Science, National University, Indonesia \\ *retno.widowati@civitas.unas.ac.id
}

\begin{abstract}
The divorce trend saw a rise every year. In 2018, the divorce rate in Indonesia was at 408,202 cases, up 9\% compared to the previous year. According to the data published by the Supreme Court Religious Corts (Badilag), in 2019, there have been 604,997 divorce applications received from all over Indonesia.

This study aims to identify the effect of health education on the knowledge and attitude of brides and grooms in the community health center of Duri Pulo Village Gambir SubDistrict. This was a quasi-experimental study with one-group pre-posttest design.

The results showed that the mean values of pretest and posttest were 1.75 and 3.05, respectively, showing 1.3 difference between the two. The $\mathrm{p}$ value was 0.00 , meaning that the $\mathrm{p}$ value $<0.05$, hence, Ho was rejected.

There was an effect of health education on the knowledge and attitude of brides and grooms. For the health center in question, the researcher is expected to hold a health outreach or education on the knowledge and attitude of brides and grooms.
\end{abstract}

Keywords : Brides and Grooms, Health Education, Knowledge, Attitude. 


\section{STRADA Jurnal Ilmiah Kesehatan}

DOI: $10.30994 /$ sjik.v9i2.342

ISSN: 2252-3847 (print); 2614-350X (online)

Vol.9 No.2 November 2020 Page.567-571

\section{BACKGROUND}

The divorce trend steadily increased every year. In 2018, the divorce rate in Indonesia was at 408,202 cases, up 9\% compared to the previous year. The leading factor for divorces is too much conflict and arguing with 183,085 cases. Economic factor follows in second with 110,909 cases (Central Bureau of Statistics, 2019). Other problems include abandonment (17.55\%), domestic violence (2.15\%), and alcoholism (0.85).

The high rate of divorces in the past three years was caused by financial or economy problems that incite domestic conflicts between husband and wife and ultimately leads to a divorce (Religious Courts, 2019).

Cases mentioned above imply the importance of premarital health information, counselling, examination and education for brides and grooms prior to their fateful day. Soon-to-be newlyweds as individuals that are about to enter the gate of marriage are in great need of information and education on the reproductive health, especially pertaining to proper pregnancy planning for a healthy baby and safe delivery (Kemenkes Ri, 2015).

Before stepping into the marriage scene, brides and grooms are advised to have a medical examination in healthcare facilities. In the Regulation of the Governor of DKI Jakarta Number 185 of 2017, it is stated that midwives are in charge of conducting Communication, Information and Education or delivering appropriate health education so that brides and grooms are prepared to lead a married life.

\section{METHODS}

This study employed a quantitative approach. Data used to analyze quantitative approach were numeric data. This a quasi-experimental study with one-group pre-posttest design.

The population in this study was all brides and grooms having a health check up in the Community Health Center of Duri Pulo Village. 20 respondents as the sample were taken using purposive sampling technique.

In order to facilitate the study, the researcher utilized Google forms to devise a questionnaire. They made a dedicated WhatsApp group for brides and grooms to distribute the pretest and posttest questions, start an open discussion between the respondents and create interventions to boost their knowledge in the form of PowerPoint and leaflets.

\section{RESULTS}

\section{Normality Test}

Table 4.1 Normality Test of Health Education Pretest and Posttest of the Knowledge and Attitude of Brides and Grooms

\begin{tabular}{|c|c|c|}
\hline \multirow[t]{2}{*}{ Variable } & \multicolumn{2}{|c|}{ Bride and Groom Health Education } \\
\hline & Pretest & Posttest \\
\hline Kno & 0.43 & 0.10 \\
\hline Attitude & 0.50 & 0.33 \\
\hline
\end{tabular}

Based on the data normality test using Kolmogorov Smirnov in Table 4.1, for the knowledge variable, the pretest result was 0.43 and the posttest result was 0.10 , greater than the significance level of 0.05 . As for the attitude variable, the pretest was 0.50 and the posttest was 0.33 , each is greater than the significance level of 0.05 . Thus, overall, it could be concluded that all data analysis units were distributed normally. 


\section{STRADA Jurnal Ilmiah Kesehatan}

DOI: $10.30994 /$ sjik.v9i2.342

ISSN: 2252-3847 (print); 2614-350X (online)

Vol.9 No.2 November 2020 Page.567-571

Bivariate Analysis

Table 4.2 The Effect of Health Education on the Knowledge of the Brides and Grooms

\begin{tabular}{lllll}
\hline & \multicolumn{4}{l}{ Paired sample t-test } \\
\cline { 2 - 5 } Group & Mean & SD & $\begin{array}{l}\text { SE } \\
\text { Mean }\end{array}$ & P Value \\
\hline Pretest & 1.75 & 1.38 & 0.30 & 0.00 \\
Posttest & 3.05 & 0.94 & 0.21 & \\
\hline
\end{tabular}

Based on Table 4.2, the mean values for pretest and posttest were 1.75 and 3.05, respectively, showing 1.3 difference between the two. The $p$ value was 0.00 , meaning that the $\mathrm{p}$ value $<0.05$, hence, Ho was rejected. Thus, the provision of health education to soonto-be newlyweds in the Community Health Center of Duri Pulo Village was shown to boost their knowledge.

Table 4.3 The Effect of Health Education on the Attitude of the Brides and Grooms

\begin{tabular}{lllll}
\hline \multirow{2}{*}{ Group } & \multicolumn{4}{l}{ Paired sample t-test } \\
\cline { 2 - 5 } & Mean & SD & $\begin{array}{l}\text { SE } \\
\text { Mean }\end{array}$ & P Value \\
\hline Pretest & 7.30 & 1.3 & 0.29 & 0.00 \\
Posttest & 8.95 & 0.9 & 0.21 & \\
\hline
\end{tabular}

Based on Table 4.3, the mean values for pretest and posttest were 7.30 and 8.95, respectively, showing 1.65 difference between the two. The $\mathrm{p}$ value was 0.00 , meaning that the $\mathrm{p}$ value $<0.05$, hence, Ho was rejected. Thus, the provision of health education to soon-to-be newlyweds in the Community Health Center of Duri Pulo Village was shown to improve their attitudes.

\section{DISCUSSION}

As the results show, prior to the provision of health education, $13(65 \%)$ respondents were in good category and $7(35 \%)$ respondents were in the poor category in terms of knowledge. After health education was given, all $20(100 \%)$ respondents were in the good knowledge category. Meanwhile, in terms of attitude prior to health education, 15 (74\%) respondents were in the high category and $5(25 \%)$ respondents were in the low category. Afterward, $18(90 \%)$ of them joined the high category and only $2(10 \%)$ of them were still in the low category.

According to the results of the study by Hidayati (2016), providing health education significantly improved the knowledge level of brides and grooms. What separates Hidayati's and this study is that Hidayati touched on the relationship between knowledge level about premarital health with brides and grooms' preparedness for a marriage, while this study discusses the effect of health education on the knowledge and attitude of brides and grooms.

These results showed an improvement in the score of knowledge and attitude of the brides and grooms after and before receiving health education in the form of outreach, discussion and intervention. In this case it is safe to say that the methods used in this study can boost knowledge. It was in line with the study by Susanti and Rustam (2016) on the effect of reproductive health courses on the knowledge and attitude of brides and grooms 


\section{STRADA Jurnal Ilmiah Kesehatan}

DOI: $10.30994 /$ sjik.v9i2.342

ISSN: 2252-3847 (print); 2614-350X (online)

Vol.9 No.2 November 2020 Page.567-571

in Koto Tangah Sub-District. Therefore, the researcher argued that providing health education could improve the knowledge and attitude of brides and grooms.

\section{Bivariate Analysis}

\section{The Effect of Health Education on the Knowledge of Brides and Grooms}

The results showed that the analysis using paired t-test on the knowledge of brides and grooms obtained a mean difference of 1.3.

Knowledge can be defined as the result of human sensing or knowing of an object through their senses. Humans possess five senses to sense objects around them, namely sight, hearing, smell, taste and touch. In producing knowledge those senses are influenced by the intensity of attention and perception toward an object. A person's knowledge is mostly obtained through the sense of hearing and sight (Notoatmodjo, 2014).

The study by Dewi Susanti (2017) found that premarital health education has an effect on the knowledge level of brides and grooms (p-value of 0.001) in Lubuk Begalung Sub-District, Padang City in 2017. This was in line with the result in this study indicating a relationship between health education the knowledge and attitude of brides and grooms (pvalue of 0.00) in the Community Health Center of Duri Pulo Village.

\section{The Effect of Health Education on the Attitude of Brides and Grooms}

The results showed that the analysis using paired t-test on the attitude of brides and grooms obtained a mean difference of 1.65.

According to the researcher premarital health education for brides and grooms is necessary and highly beneficial to boost their knowledge on reproductive health which was lacking at that time. The delivery of health education also plays an important role for their knowledge on marriage and reproductive health.

This result was in line with the study by Rahim on women's knowledge and attitudes regarding reproductive health with bride and groom courses in 2016.

\section{CONCLUSIONS}

Based on the results of the study, it can be concluded that The analysis on knowledge obtains p-value of 0.00 meaning that health education has a significant effect on the knowledge of the brides and grooms. The analysis on attitudes obtains p-value of 0.00 meaning that health education has a significant effect on the knowledge of the brides and grooms.

\section{REFERENCES}

Amalia R., Siswantara P., 2017. Efektivitas penyuluhan kesehatan reproduksi pada calon pengantin di Puskesmas Pucang Sewu. Surabaya.

Badan Pusat Statistik. 2019. Jumlah Nikah, Talak dan Cerai, serta Rujuk (Pasangan Nikah), https://www.bps.go.id/linkTableDinamis/view/id/893.

Badilag. 2019. Direktorat Jenderal Badan Peradilan Agama Indonesia. Jakarta.

Gubernur D.K.I. 2017. Peraturan gubernur daerah ibukota provinsi Daerah Khusus Ibukota Jakarta nomor 185 tahun 2017 tentang Konseling Dan Pemeriksaan Kesehatan Bagi Calon Pengantin, Jakarta.

Hadya, D. 2020, Ramai RUU ketahanan keluarga, berapa angka perceraian di Indonesia, http://databoks.kadata.co.id, diakses 20 Februari 2020.

Hidayati R.D. 2016. Hubungan Tingkat Pengetahuan terhadap Kesehatan Reproduksi dengan Kesiapan Menikah pada Calon Pengantin. Yogyakarta. 


\section{STRADA Jurnal Ilmiah Kesehatan}

DOI: $10.30994 /$ sjik.v9i2.342

ISSN: 2252-3847 (print); 2614-350X (online)

Vol.9 No.2 November 2020 Page.567-571

Kementerian Kesehatan Republik Indonesia. 2015. Мепијu Persalinan yang Aman dan Selamat agar Ibu Sehat Bayi Sehat. DEPKES.

Nor. 2017. Konseling Kesehatan Pra Nikah Terhadap Minat Penundaan Kehamilan Berisiko Pada Calon Pasangan Usia Subur Dibawah 20 Tahun. Jombang.

Notoatmodjo S. 2014. Ilmu Perilaku Kesehatan. Jakarta: Rineka Cipta.

Rahim R. 2016. Pengetahuan dan Sikap Wanita tentang Kesehatan Reproduksi dengan Kursus Calon Pengantin. Yogyakarta.

Susana Y. 2019. Pentingnya Kesetaraan Gender untuk Membangun Keluarga Bahagia. https://gaya.tempo.co/, di akses 15 oktober 2019.

Susanti D, Rustam Y. (2016). Pengaruh Kursus Kesehatan Reproduksi Terhadap Pengetahuan dan Sikap Calon Pengantin di Kecamatan Koto Tangah. Padang.

Susanti, D. 2017. Pengaruh Pendidikan Kesehatan Pranikah Terhadap Pengetahuan Dan Sikap Calon Pengantin Di Lubuk Begalung Padang. Kota Padang.

Virna., Wahyudi, N. 2019. Angka gugatan perceraian di jakarta pusat meningkat. https://www.antaranews.com/, di akses 28 februari 2019.

Wawan A., Dewi M., 2011. Teori dan Pengukuran Pengetahuan Sikap dan Perilaku Manusia.Yogyakarta: Nuha Medika. 